\title{
Prevalence of HBsAg and HCV Infection in Pregnant Females of Lahore
}

\author{
Mati Ullah ${ }^{1}$, Muhammad Atif ${ }^{2}, \operatorname{Romman}_{\mathrm{Aziz}^{3}, \text { Muhammad Imran }}^{4}$, Muhammad Imran ${ }^{5}$, \\ Ahmed Bilal Waqar ${ }^{6}$ \\ ${ }^{1}$ University Institute of Medical Laboratory Technology (UIMLT), Faculty of Allied Health Sciences, University of Lahore \\ ${ }^{2,3,5}$ Department of Medical Laboratory Sciences (DMLS), Faculty of Health and Allied Sciences, Imperial College of Business \\ Studies, Lahore \\ ${ }^{\mathrm{c}}$ Department of Diet and Nutritional Sciences (DDNS), Faculty of Health and Allied Sciences, Imperial College of B usiness \\ Studies, Lahore \\ ${ }^{6}$ Imperial Post Graduate Medical Institute (IPGMI), Faculty of Health and Allied Sciences, Imperial Coll ege of Business Studies,
} Lahore

\begin{abstract}
This study was designed to detect the prevalence of Hepatitis $B$ \& $C$ infection in pregnant females of Lahore.This study was held from May 2014 to September 2014 in the department of Gynaecology, Jinnah hospital, Lahore. Bloodsamples werecollected from hospitalized pregnant women and tested for anti HCV antibodies and HBsAg by means of Immunochromatographic (ICT) test device. Informed written consent was taken from the patients. Data was entered and analyzed using SPSS version 19.200 women were tested for Hepatitis $B \& C$. The prevalence of Hepatitis $B$ and $C$ in pregnant females was found to be $1.5 \%$ and $12.5 \%$ respectively. Route of transmission of these deadly viruses is by contaminated injections, blood transfusions and surgical operations and these infections can transfer from mother to infant. We conclude from this study that prevalence of Hepatitis $C$ is more in pregnant females as compared to the prevalence of Hepatitis $C$ in general population which is around $5 \%$. So it is of prime importance to screen pregnant females for Hepatitis $B$ \& $C$ infectionsto prevent serious outcomes of these infections in the mother and the fetus.
\end{abstract}

Keywords: Prevalence, Hepatitis, HCV, HBsAg, Pregnancy

\section{Introduction}

Pregnancy represents stress period not only for the mother but also for the infants. Infections due to hepatitis Band $\mathrm{C}$ viruses are significant health problems in the whole world. Viral hepatitis is acute liver disease, cause by HBV\&HCV $\&$ this is a foremost public health dilemma, mainly in developing countries (Umar et al., 2010).

$\mathrm{HCV}$ is a transmissible liver infection that ranges in severity from a mild illness to a lethal disease, long-term sickness that attacks the liver.HBV is a DNA virus which is transmitted by sexual contact, blood transfusion, surgical procedures and from mother to offspring and it affects 1.25 million people in the US and approximately 350 to 400 million people around the global (WHO, 2011).

A current study from Pakistan showed HCV frequency as $3 \%$ in the common population. A broad range of HCV sero occurrence was reported in the pregnant females ranges from $3.3 \%$ to $29.1 \%$ with a prevalence of $7.3 \%$ (Umar et al., 2010).

HBV infections occur worldwide \& represent a severe public health problem(WHO, 2011).Nearby 65 million people who have HBV infection live in Africa(Kramvis, \& Kew, 2007). Common practices that expose people to HBV infection like unprotected sex, nose \& ear piercing as well as tattoos on body have higher occurrence in certain areas but not necessary in pregnancy (Dwivedi et al., 2007).
According to a research 24,000 newborns each year in the United States are born by HBV positive mothers. Those HBsAg-positive mothers are a symbol of elevated viral spread and post-partum HBV transmission rates have been noticed to be high up to $85 \%$ to $90 \%$. Number of people infected with hepatitis B or $\mathrm{C}$ rarely ever shows any signs in the early stage of the disease, even they can still pass on the virus to others (Ahmed et al., 2006; stevens et al., 1975).Pregnancy provides a chance for females to be screened for $\mathrm{HBV}$ and $\mathrm{HCV}$. $\mathrm{HCV}$ infection is a major public health problem in the whole world. According to WHO about $3 \%$ of the world's populations are infected with $\mathrm{HCV}$, most of these cases arise in Africa, which is investigated to have the highest $\mathrm{HCV}$ occurrence rate (WHO, 1999; Madhava et al., 2002).

Both HBV and HCV are major causes of morbidity, mortality and serious public health crisisin whole world and also in Pakistan(Khattak, 2009).In Pakistan it is estimated that at least nine million people have $\mathrm{HBV}$ infection and over fourteen million are persistently infected with HCV(Hakim, 2008; Hakeem, 2006)In Pakistan, viral hepatitis is endemic with regular outbreaks. Although the prevalence differ from region to region and society to society due to changes in nationality and socioeconomic state (Haider, 1994; Mujeeb, 1998) both these infections are related to serious morbidity and mortality (Oliveira, 1994).

\section{Material and Methods}

Present study was done to determine the laboratory based prevalence of $\mathrm{HCV}$ and $\mathrm{HBV}$ in pregnant females. This 


\section{International Journal of Science and Research (IJSR) \\ ISSN (Online): 2319-7064 \\ Index Copernicus Value (2013): 6.14 | Impact Factor (2015): 6.391}

study was conducted in Jinnah hospital Lahore from May 2014 to September 2014. Total $200 \quad(n=200)$ pregnant females aged between 18-40 years, were selected using simple random sampling technique from Gynecology unit. Blood samples were collected from every pregnant female for the determination of HBV \& HCV.

Blood specimen was collected from the anti-cubital vein without venous stasis using a dry disposable sterile syringe. $3 \mathrm{ml}$ of blood was collect into EDTA tubes. The sample was labelled with patient's age, sex sand laboratory number. Testing of HBV and HCV was done by immunochromatographic (ICT) method. The results were entered and analyzed on SPSS 19.

\section{Results}

A total number of 200 women of the Gynecology ward of the Jinnah hospital were included in this study and they were tested for Hepatitis B \& C. Mean age group of the women was $18-40$ years. The Sero-positivity of HCV was $12.5 \%$ as shown in (Table and Figure 1) and Sero-positivity of Hepatitis B was found to be $1.5 \%$ as shown in (Table and Figure 2).

Table 1: Table Showing Results of HCV

\begin{tabular}{|c|c|c|}
\hline$H C V$ & Frequency & Percent \\
\hline Positive & 25 & 12.5 \\
\hline Negative & 175 & 87.5 \\
\hline Total & 200 & 100.0 \\
\hline
\end{tabular}

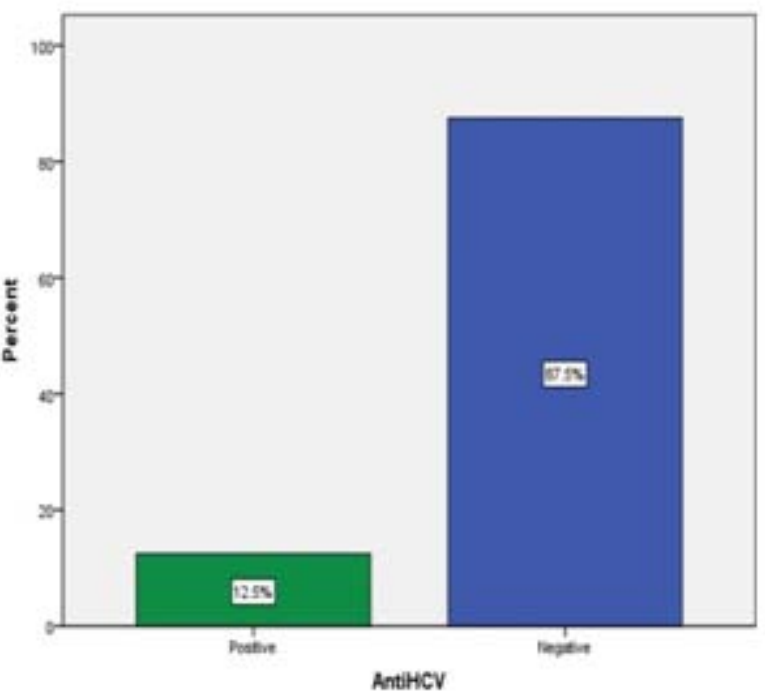

Figure 1: Figure Showing Results of HCV

Table 2: Table Showing Results of HBsAg

\begin{tabular}{|c|c|c|}
\hline HBsAg & Frequency & Percent (\%) \\
\hline Positive & 3 & 1.5 \\
\hline Negative & 197 & 98.5 \\
\hline Total & 200 & 100.0 \\
\hline
\end{tabular}

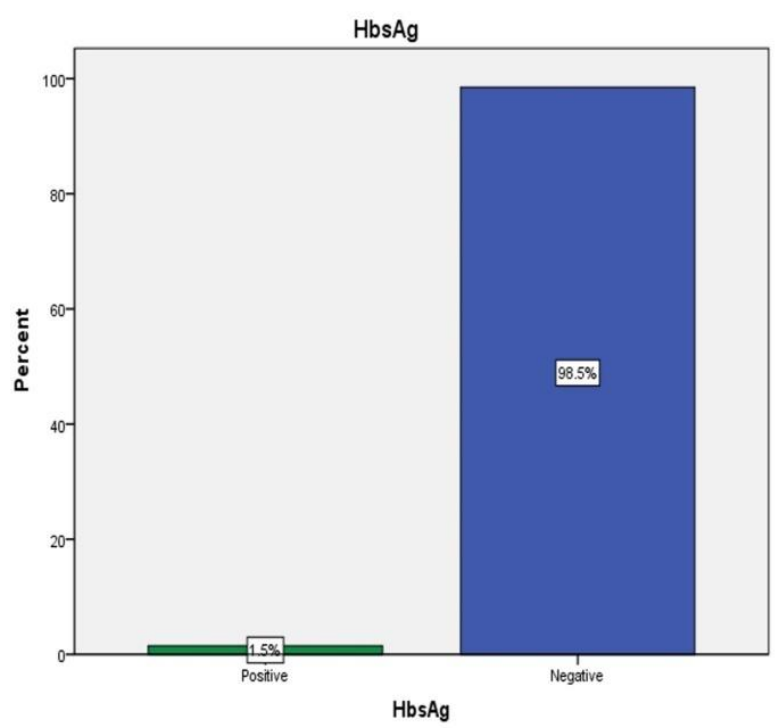

Figure 2: Figure Showing Results of HBsAg

$36.0 \% \mathrm{HCV}$ found between age group 18-25 years, 52.0\% $\mathrm{HCV}$ found between the age group 26-32 and, $12.0 \%$ were found between 33-40 age group as shown in (Table and Figure 3).

Table 3: Table Showing Age Groups of HCV Positive Patients

\begin{tabular}{|c|c|c|}
\hline Age Groups & Frequency & Percent (\%) \\
\hline $18-25$ & 9 & 36.0 \\
\hline $26-32$ & 13 & 52.0 \\
\hline $33-40$ & 3 & 12.0 \\
\hline Total & 25 & 100.0 \\
\hline
\end{tabular}

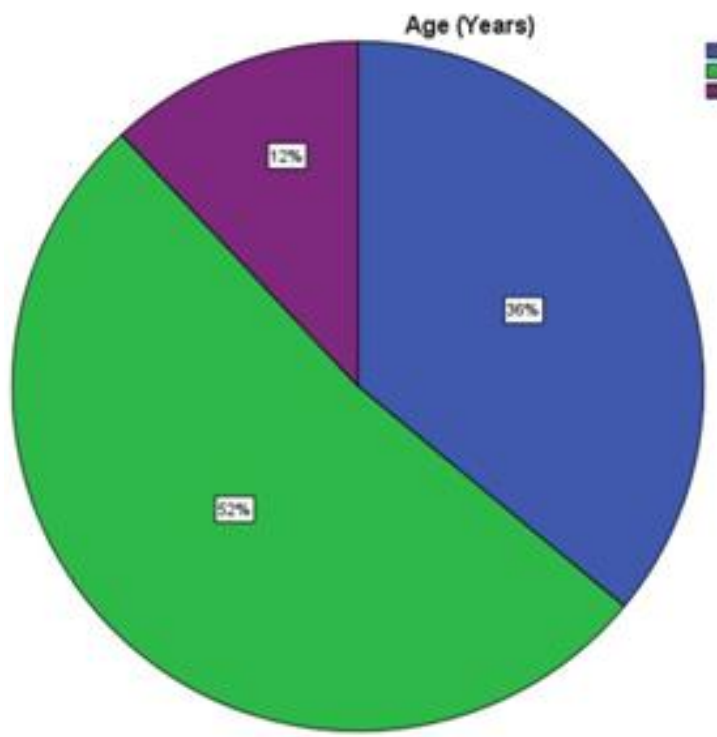

Figure 3: Figure Showing Age Groups of HCV Positive Patients

\section{Discussion}

This study has indicated a link between hepatitis and different maternal and perinatal complications.HBV \& HCV are the major infections all over the world. In infected pregnant females these infections arises the possibility to transfer HBV and HCV infection to their infants (Fomulu, 2013)According to World Health Organization, In Southeast

\section{Volume 5 Issue 8, August 2016}




\section{International Journal of Science and Research (IJSR) \\ ISSN (Online): 2319-7064 \\ Index Copernicus Value (2013): 6.14 | Impact Factor (2015): 6.391}

Asia, an average person receives four injections per year, among most of which are needless and up to $75 \%$ are risky or reused (Khokhar, 2004).

In United States the occurrence of Hepatitis B and C is found to be 0.5 to $1.5 \%$ and $1 \%$ respectively(Munoz, 2005). In Pakistan there are 1.5 million blood product unitstransfused each year which represents a great risk for the spread of HBV and HCV infections (Kazi, 1999).A previous study conducted in Lahore on pregnant females show anti-HCV positivity of $7.3 \%$ and HBsAg positivity of $2.2 \%$ (Batool, 2008).In our study the prevalence of $\mathrm{HBV}$

\section{References}

[1] Ahmad, I., Khan, S.B., Rahman, H.U., Khan, M.H., \& Anwar S.(2006). Frequency of Hepatitis B and Hepatitis C among cataract patients. Gomal Journal of Medical Sciences. 4:61-64.

[2] Batool, A., Bano, K.A., Khan, M.I., \& Hussain, R.(2008). Antenatal screening of women for Hepatitis B and $\mathrm{C}$ in an out-patient department. Journal of Dow University of Health Sciences. 2(1):32-5.

[3] Dwivedi, M., Misra, S.P., Misra, V., Pandey, A., Pant, S., Singh, R. \& Verma, M. (2011). Seroprevalence of hepatitis $\mathrm{B}$ infection during pregnancy and risk of perinatal transmission. Indian Journal of Gastroenterology. 30:66-71.

[4] Fomulu, N.J., Morfaw, F.L., Torimiro, J.N., Nana, P., Koh, M.V., \& William, T. (2013). Prevalence, correlates and pattern of Hepatitis B among antenatal clinic attenders in Yaounde-Cameroon: is perinatal transmission of $\mathrm{HBV}$ neglected in Cameroon. BMC Pregnancy Childbirth. 13:1-10.

[5] Haider, Z., Khan, A.A., Rehman, K., Janjua, M.I., Iqbal, J., \& Chishti, M.A. (1994). Sero-diagnosis of viral hepatitis in 93 patients admitted with acute hepatitis in three different teaching hospitals in Lahore. Journal of Pakistan Medical Association. 44:182-4.

[6] Hakeem, K., Khan, M.S., \& Abdullah, M. (2006). Prevalence of HBsAg and anti HCV in pregnant ladies attending antenatal clinical at sheikh Zayed medical Complex, Rahim yar khan. Journal of Services Institute of Medical Sciences.2 (3): 6-8.

[7] Hakim, S.T., Kazmi, S.U., \& Bagasra, O. (2008). Seroprevalence of hepatitis B and C genotypes among young apparently healthy females of Karachi-Pakistan. Libyan Journal of Medicine. 3(2): 66-70.

[8] Kazi, B.M. (1999). Standards and guidelines for blood transfusion services. Islamabad, Pakistan: World Health Organization/ National Institute of Health, Federal Health Ministry, Government of Pakistan.

[9] Khattak, S.T., Marwat, M.A., Khattak, I.D., Khan, T.M., \& Naheed, T. (2009). Comparison of Frequency of Hepatitis B and Hepatitis C in Pregnant Women in Urban and Rural area of District Swat. Journal of Ayub Medical College. 21(2) 12-15.

[10] Khokhar, N., Gill, M.L., \& Malik, G.J. (2004). General seroprevalence of hepatitis $\mathrm{C}$ and hepatitis $\mathrm{B}$ virus infections in population. Journal of the College of Physicians and Surgeons of Pakistan. 14:534-6.

[11] Kramvis, A., \& Kew, M.C. (2007). Epidemiology of hepatitis B virus in Africa, its genotypes and clinical infections was $1.5 \%$ and the prevalence of hepatitis $\mathrm{C}$ is $12.5 \%$ which is in accordance with the previous studies.

\section{Conclusion}

There is an increased prevalence rate of $\mathrm{HCV}$ than $\mathrm{HBsAg}$ in pregnant females. Additional studies are required toexplain the increased prevalence of anti-HCV and infection among pregnant females. Awareness campaigns regarding the route of transmission of $\mathrm{HBV}$ and HCVand vaccination of $H B V$ can reduce the risk of their spread and save mothers and offspring from these deadly infections.

associations of genotypes. Hepatology Research, 37:S9-S19.

[12] Madhava, V., Burgess, C., \& Drucker, E. (2002). Epidemiologyof chronic hepatitis C virus infection in sub-Saharan. The Lancet Infectious Diseases. 2:293-302.

[13] Mujeeb, S.A. (1998). Seroprevalence and pattern of viral hepatitis in Pakistan. The journal of Infectious Disesases. 5:20-1.

[14] Munoz, P.S., Robert, S., \& Sheffied, J. (2005). Prevalence of hepatitis B and C in pregnant women who are infected with HIV. American Journal of Obstetrics and Gynecology. 3 (1):1270-3

[15] Oliveira, M.L., Bastes, F.I., Telles, P.R., Yoshida, C.F., Schatzmayr, H.G., \& Paetzold, U. (1999). Prevalence and risk factors for $\mathrm{HBV}, \mathrm{HCV}$ and $\mathrm{HDV}$ infections among injecting drug users. Brazilian Journal of Medical and Biological Research.32:1107-14.

[16] Stevens, C.E., Beasley, R.P., Tsui, J., \& Lee W.C. (1975). Vertical transmission of hepatitis B antigen in Taiwan. The New England Journal of Medicine. 292:771-4.

[17]Umar, M., Bushra H.T., Ahmed, M., Khuram, M., Usman, S., \& Arif, M. (2010). Hepatitis C in Pakistan: A Review of Available Data. Hepatitis Monthly, 10(3):205-214.

[18] World Health Organization (1999). Global surveillance and control of hepatitis C. Report of a WHO Consultation organized in collaboration with the Viral Hepatitis Prevention Board, Antwerp, Belgium. Journal of Viral Hepatitis. 6:35-47.

[19] World Health Organization. (2011). Hepatitis B. Fact Sheet No. 204. Geneva, Switzerland. 